DOI: $10.15290 /$ bsl.2021.19.14

Creative Commons License: CC BY-SA 4.0

https://creativecommons.org/licenses/by-sa/4.0/deed.en

\author{
Michał Fałtynowicz \\ Wydział Filologiczny \\ Uniwersytet Gdański \\ e-mail: michal.faltynowicz@phdstud.ug.edu.pl \\ ORCID: 0000-0002-8136-0029
}

\title{
Różne oblicza elegii w poezji Adama Zagajewskiego
}

W swojej poezji Adam Zagajewski często odnosi się do przeszłości, wspomina minione wydarzenia, miejsca, które uległy zmianom i ludzi, którzy już odeszli. Odwołuje się też do historii - tej odległej oraz tej bliższej. Czyniąc bohatera lirycznego swoich wierszy strażnikiem pamięci, poeta chętnie sięga po formę elegijną, która przejawia się w jego twórczości w wielu odmianach.

Elegia jako gatunek „rozwijała się VII-VI wieku p.n.e. w liryce greckiej i rzymskiej, dzieląc się tematycznie na elegie miłosne, polityczne, biesiadne, dydaktyczne i in." ${ }^{1}$. Na grunt polski formę tę przeniósł Jan Kochanowski, który wzorował się na utworach antycznych ${ }^{2}$. Jak zauważa Roman Doktór, „nazwa gatunkowa «elegia» w rozumieniu antycznym jest już kategorią skostniałą i nie mającą żadnego znaczenia dla dzisiejszego wyobrażenia o elegii"3, ponieważ jeszcze w renesansie przestawały obowiązywać normy metryczne, charakteryzujące ten gatunek, a ważniejszymi stały się cechy, które „dawały się rozpoznać jako jej szczególnie bliskie. Chodziło przede

\footnotetext{
1 A. Legeżyńska, Gest pożegnania. Szkice o poetyckiej świadomości elegijno-ironicznej, Poznań 1999, s. 17.

${ }^{2}$ H. Piotrowska, Elegia, w: Słownik literatury polskiego Oświecenia, red. T. Kostkiewiczowa, Wrocław 1977, s. 106.

3 R. Doktór, Polska elegia oświeceniowa, Lublin 1999, s. 14.
} 
wszystkim o tonację, nastrój, tematykę i pewne upodobania semantyczne. Zespół tych atrybutów chciałbym nazwać jakością gatunkową, którą powszechnie nazywa się elegijnością" ${ }^{4}$. Charakteryzując elegię oświeceniową, Doktór dzieli jej cechy na trzy grupy: identyfikujące, pożądane oraz fakultatywne ${ }^{5}$. Warto przyjrzeć się tym pierwszym, ponieważ wydają się one aktualne również w późniejszych epokach i ich rozpoznanie pozwala przynajmniej zadać pytanie, czy dany utwór można sklasyfikować jako elegijną formę. Rozwój elegii $\mathrm{w}$ oświeceniu jest istotny ze względu na dalsze jej losy w literaturze polskiej, co badacz wyraźnie podkreśla:

Innymi słowy, w ostatnich dwudziestu latach XVIII i w pierwszych dziesiątkach wieku XIX powstała elegia $\mathrm{w}$ takim kształcie, że nie tylko $\mathrm{w}$ niczym nie przypominała pierwotnego gatunku antycznego, nie tylko znacząco odbiegała od realizacji znanych z XVI i XVII wieku, ale z powodzeniem wyznaczała pewne "normy", których nie mogła zlekceważyć poezja romantyczna, od których wreszcie nie ma powodu odrywać się poezja XX wieku'

Elegia zmieniała się przez wieki, jednak - jak zauważa Doktór - można wskazać elementy wspólne, które pojawiają się w lirykach tworzonych w późniejszych epokach. Istotną cechą tego gatunku - tak ważną w elegiach Zagajewskiego - jest temat pamięci, co podkreśla badaczka literatury polskiej wieku XIX, Bernadetta Kuczera-Chachulska: „hasło «elegia» uruchamia [...] zasadniczy łańcuch: elegia - liryczność - osoba - pamięć. Ta ostatnia zdaje się być nadzwyczaj ważna w strukturze form elegijnych, jej wyrazista rola ujawnia się szczególnie w tekstach Mickiewicza"7. Ulegając różnym transformacjom, elegia przetrwała aż do dzisiaj i jest stale obecna w poezji współczesnej $^{8}$. Jak zauważa Anna Legeżyńska:

Od Elegii duinejskich (1923) R. M. Rilkego, tłumaczonych także przez polskich poetów, wzorzec elegijności na stałe poszerza się o refleksję filozoficzną i metafizyczną. Dziś mianem elegii najczęściej określają swoje wiersze poeci podejmujący tematy upływu czasu, starości i śmierci ${ }^{9}$.

\footnotetext{
4 Tamże, s. 14-15.

5 Tamże, s. 72-73. Doktór do cech identyfikujących zalicza: utratę jakiegoś dobra i porównanie stanu obecnego z przeszłym oraz specjalną nastrojowość; do cech pożądanych: narzekanie na los, wnikanie w samego siebie oraz skłonność do uogólniania przeżyć; do cech fakultatywnych: potrzebę obcowania z naturą i upodobania semantyczne [tamże, s. 72-73].

6 Tamże, s. 229.

7 B. Kuczera-Chachulska, Przemiany form i postaw elegijnych w liryce polskiej XIX wieku, Warszawa 2002, s. 21.

8 A. Legeżyńska, Gest pożegnania. Szkice o poetyckiej świadomości elegijno-ironicznej, s. 17-18.

9 Tamże, s. 18.
} 
Anna Czabanowska-Wróbel, pisząc o wykorzystywaniu tego gatunku przez Zagajewskiego, stwierdza, że elegia i elegijność w jego twórczości: „to rozległy temat, gdyż wiele wierszy można potraktować właśnie jako realizację tego gatunku [...]. Autor Powrotu rozwija dwie wywodzące się z antyku główne odmiany dwudziestowiecznej kontynuacji starego gatunku - autobiograficzną i żałobną - elegię o zmarłych" ${ }^{\prime 10}$. Na stałą obecność tonacji elegijnej w poezji krakowskiego poety wskazuje również Derek Walcott:

Na pozór wiersze Zagajewskiego zdają się kontynuować nowoczesną tradycję, ale w rzeczywistości są one echem skandowania. Regularność ich dźwiękowego kształtu jest hołdem złożonym temu, czego nam dziś brakuje i czego odejście opłakujemy. Łączy je stałość tonu elegijnego ${ }^{11}$.

Próbując wyjaśnić, dlaczego właśnie w tym gatunku literackim odnalazł się autor Dwóch miast, Czabanowska-Wróbel dochodzi do wniosku, że: „Elegia jest bliska Zagajewskiemu ze względu na swój nietragiczny, łagodny i spokojny, zdystansowany charakter" ${ }^{12}$. Zarazem jednak zaznacza, że sięganie po tę formę przez Zagajewskiego wiąże się z pewnym wymogiem: „Powrót do przeszłości jest cenny, o ile jest w stanie wpłynąć na teraźniejszy stan "ja»"13. Doskonale widać to w wierszu Rachmaninow z tomu Asymetria. Utwór rozpoczyna się od refleksji: „Dawniej, kiedy słuchałem trzeciego koncertu, / nie zdawałem sobie sprawy, że dla znawców / jest to muzyka zbyt konserwatywna" [As, s. 30] ${ }^{14}$. W trzeciej, ostatniej strofie, nie tylko ma miejsce powrót do teraźniejszości, ale następuje połączenie dwóch stadiów tożsamości bohatera - chłopca oraz dorosłego mężczyzny - będących zarazem jednością, jak i oddzielnymi bytami: „Teraz, [...] / [...] podziwiam mistrzostwo jej gry, / [...] a jednocześnie ten chłopiec, / którym kiedyś byłem, próbuje zrozumieć, nie bez trudu, / co się spełniło a co zgasło. Co żyje" [As, s. 30].

Czabanowska-Wróbel niektóre wiersze Zagajewskiego (na przykład: Dom, Czarna rzeka, W kropli deszczu, Siostry mitosierdzia, How High the Moon) zalicza do elegii dzieciństwa ${ }^{15}$, podkreślając, że wspomnienia lat dziecię-

10 A. Czabanowska-Wróbel, Poszukiwanie blasku. O poezji Adama Zagajewskiego, Kraków 2005, s. 153.

11 D. Walcott, Elegista, przeł. R. Gorczyńka, w: I cień i światło... O twórczości Adama Zagajewskiego, red. A. Czabanowska-Wróbel, Kraków 2015, s. 22.

12 A. Czabanowska-Wróbel, Poszukiwanie blasku. O poezji Adama Zagajewskiego, s. 154.

13 Tamże, s. 155.

14 Cytaty z wierszy Zagajewskiego lokalizuję w tekście głównym, stosując następujące skróty tomów poetyckich: An - Anteny, Kraków 2005, As - Asymetria, Kraków 2014, NR - Niewidzialna ręka, Kraków 2009, Pł - Płótno, Paryż 1990, Po - Powrót, Kraków 2003, PŻ - Prawdziwe życie, Kraków 2019, ZO - Ziemia ognista, Poznań 1994.

15 A. Czabanowska-Wróbel, Poszukiwanie blasku. O poezji Adama Zagajewskiego, s. 155. 
cych i młodzieńczych powracają niemal w każdym jego tomie poetyckim. W zbiorze Prawdziwe życie (2019) znajduje się na przykład wiersz Arkońska 7, w którym poeta wspomina swoich gliwickich sąsiadów z okresu dzieciństwa: „Na pierwszym piętrze mieszkał Wojtek Pszoniak / a na drugim ja, słuchałem radia / i czytałem Dzieci kapitana Granta. / Uwielbiałem profesora Paganela” [PŻ, s. 13]. Jednak utwór kończy się zdaniem: „A ulice w zimie i w lecie stały / nieruchomo jak posągi / na Wyspie Wielkanocnej / i patrzyły tylko w jedną stronę" [PŻ, s. 13], którego odczytanie w kontekście innych wierszy oraz eseju Dwa miasta może prowadzić do wniosku, że mowa tutaj o patrzeniu w stronę Lwowa. Wiersz będący elegią dzieciństwa, staje się zarazem elegią o Lwowie - mieście utraconym, zmitologizowanym w środowisku mieszkańców Gliwic, w którym wychował się Zagajewski. Jak zauważa Czabanowska-Wróbel:

Pomiędzy osobistym autobiograficznym typem elegii a elegią stanowiącą pochwałę wielkich ludzi sytuują się elegie o miastach. Najlepsza z nich, Jechać do Lwowa, ma charakter wielkiej syntezy dwudziestowiecznych dziejów miasta i jego mieszkańców ${ }^{16}$.

Wiersz Arkońska 7 byłby zarazem elegią o dzieciństwie, elegią o ulicy w Gliwicach, a także elegią o Lwowie - mieście, na które wielu bohaterów w twórczości Zagajewskiego spoglądało z utęsknieniem. Przyjmując takie założenie, warto przywołać uwagi Wallcotta na temat obrazu tego miasta w najbardziej chyba znanym poemacie Zagajewskiego Jechać do Lwowa:

Lwów wyłania się z mgły jasny jak obłok - obraz siebie samego, który dzięki sile pamięci krystalizuje się, ale też stanowi zanikającą stałość. W stłumianej poświacie języka poety Lwów jest miastem dojrzałym jak brzoskwinia zwisająca z gałęzi, połyskliwa i doskonała, jarząc się krótko jak zachód słońca w tropikach. Jest zarazem Starym i Nowym Testamentem [...]. Lwów Zagajewskiego jest miejscem nieosiągalnym $\mathrm{w}$ swoim spokoju ${ }^{17}$.

Z kolei Krzysztof Biedrzycki tak odczytuje intencję poety: „To wydobywanie tego miasta $z$ otchłani niepamięci, wskrzeszanie go albo i stwarzanie na nowo. To zarazem zwracanie uwagi w stronę świata $\mathrm{z}$ jego bogactwem i rozmaitością” ${ }^{18}$. I dalej dodaje: „Poemat Zagajewskiego jednocześnie skierowany jest ku przeszłości i zanurzony jest w teraźniejszości"19. Słowa te

\footnotetext{
16 Tamże, s. 161.

17 D. Walcott, Elegista, s. 25.

18 K. Biedrzycki, Poezja i pamięć. O trzech poematach Czesława Miłosza, Zbigniewa Herberta i Adama Zagajewskiego, Kraków 2008, s. 230.

19 Tamże.
} 
potwierdzają, że bohater liryczny Zagajewskiego świadom jest nierozerwalnego związku między przeszłością a teraźniejszością, między tymi dwiema czasoprzestrzeniami.

Nie tylko Lwów jest tematem elegii Zagajewskiego. Ich bohater, będący w nieustannej podróży, wspomina także Gliwice czy Kraków. Jak zauważa Czabanowska-Wróbel: „Miasto opisane w elegijnym cyklu Powrót nie jest jedynie punktem na trasie "podróży sentymentalnej»; do czystego tonu elegijnego dołącza się ironia" ${ }^{20}$. Mniej ironii można zauważyć w elegiach, które są poświęcone konkretnym ludziom - często zmarłym członkom rodziny lub przyjaciołom poety. Dobrym przykładem są wiersze o matce, takie jak: Lotnisko w Amsterdamie czy Studniówka. Wspomnienie matki powraca także w utworze Konkurs: „i jak teraz chciałbym znowu / usłyszeć opowiadanie mamy / o konkursie, w którym prawie zwyciężyła" [As, s. 68]. Wiersz Zasuwka natomiast jest zarówno elegią o dziadku, pracowniku lwowskiego uniwersytetu, jak i elegią o Lwowie, którego obraz przywołuje „zasuwka”, będąca: „idyllicznym wspomnieniem, / broszką z Herkulanum, skarbem" [PZ̈, s. 31]. Zasuwka - niewielki przedmiot - staje się niejako nośnikiem pamięci, pobudzającym wspomnienie o świecie, którego już nie ma. Nazwanie jej „skarbem” zdradza podejście bohatera lirycznego do przeszłości. Jako strażnik pamięci właśnie w niej widzi narzędzie do wywoływania czasu minionego.

Zagajewski w wielu utworach przywołuje postacie znaczące dla kultury - pisarzy, malarzy, filozofów, z którymi się przyjaźnił, takie jak: Józef Czapski, Zbigniew Herbert i Josif Brodski. Czas jest nieubłagany i w kolejnych tomach poety pojawia się coraz więcej wierszy poświęconych "nowym” zmarłym, wśród nich Czesławowi Miłoszowi [Odchodzi wielki poeta, NR], Henrykowi Beresce [Mur, NR], C.K. Williamsowi [Charlie, PŻ].

Jaki charakter ma elegijna twórczość Zagajewskiego? Autorka Poszukiwania blasku stwierdza, że elegijny powrót tego poety do przeszłości ,jest ponadjednostkowy, nie wyłącznie prywatny, i co ważniejsze, niesentymentalny" ${ }^{21}$. Trafność tego spostrzeżenia potwierdza końcowa strofa liryku Odchodzi wielki poeta: "Gdy jednak będziemy się żegnali na długo / lub na zawsze z kimś, kogo kochamy, / poczujemy nagle, że brak nam słów / i że teraz my sami musimy mówić, / że już nas nikt nie wyręczy / - ponieważ odszedł wielki poeta" [NR, s. 48]. Na pewno nie jest to jednostkowe spojrzenie. Czy niesentymentalne? Poeta wyraża żal, ale też patrzy „praktycznie”

20 A. Czabanowska-Wróbel, Poszukiwanie blasku. O poezji Adama Zagajewskiego, s. 162.

21 Tamże, s. 161. 
na rolę poety - kogoś, kto włada słowem, jest mistrzem wyrażania myśli niewyrażalnych. Ponadto jest to gorzka elegia, na co wskazują trzy pierwsze wersy: „Naprawdę nic się nie zmienia / w zwyczajnym świetle dziennym, / kiedy odchodzi wielki poeta" [NR, s. 48]. Czabanowska-Wróbel, analizując utwór Temat: Brodski, zauważa, że: „ironiczna forma stanowi hołd dla autora [Brodskiego - M.F.] tylu gorzkich, niesentymentalnych elegii" 22, co świadczy $\mathrm{o}$ „niemożliwości powrotu do czystego elegijnego tonu w sytuacji, gdy świat rozdzierany jest przez niedające się pojednać sprzeczności" ${ }^{23}$.

\section{Strażnik pamięci ofiar Holocaustu}

Makabryczne zbrodnie, ludobójstwo, czystki etniczne, które miały miejsce w XX wieku, odcisnęły trwały ślad w ludziach kultury zachodniej. Zagajewski także musiał zmierzyć się z tymi przerażającymi faktami, co znalazło odzwierciedlenie $\mathrm{w}$ jego poezji. Aleksandra Ubertowska zauważa jednak, że „w dorobku autora Płótna jest [...] stosunkowo niewiele utworów poetyckich, w których motywy odsyłające do żydowskiej śmierci pojawiałyby się na powierzchniowym, jawnym poziomie znaczeń i organizowały całą wypowiedź" ${ }^{24}$. Nie zmienia to faktu, że w tomach poety znajdą się wiersze, których głównym tematem jest Zagłada. Najwyraźniejszym przykładem są utwory: Oglądając Shoah w pokoju hotelowym, w Ameryce [Pł], Jedwabne [An], a także liryki dotyczące krakowskiego Kazimierza, np. Nienapisana elegia dla Żydów krakowskich [NR]. Nie tylko w nich czytelnik odnajdzie pamięć o Holocauście. Wśród wierszy Zagajewskiego:

odrębną grupę stanowią utwory, w których "toposy holocaustowe" zostały włączone w obręb konstrukcji enumeracyjnych, stanowiących tak charakterystyczny wyznacznik dykcji poetyckiej Zagajewskiego. Toposy te współtworzą wieloaspektowe, płynne znaczeniowo wypowiedzi, funkcjonując $\mathrm{w}$ ich obrębie na prawach kanonicznych formuł poetyckich i kulturowych obrazów o uniwersalnej, łatwo rozpoznawalnej treści ${ }^{25}$.

Życie w świecie, w którym miała miejsce Zagłada, dla każdego intelektualisty stanowi wyzwanie. Zagajewski także zabiera w tej sprawie głos

\footnotetext{
22 Tamże, s. 155.

23 Tamże, s. 159.

24 A. Ubertowska, Świadectwo - trauma - głos. Literackie reprezentacje Holocaustu, Kraków 2007, s. 297. W książce znajduje się rozdział w całości poświęcony Zagładzie w poezji Zagajewskiego.

25 Tamże, s. 303.
} 
we wspomnianym już wierszu Ogladajac Shoah w pokoju hotelowym, w Ameryce, którego bohater znajduje się w hotelu i ogląda w telewizji film na temat Shoah, podczas gdy za ścianą trwa przyjęcie: "goście hotelowi śpiewali happy birthday to you / a jednooki telewizor obojętnie tasował obrazy" [Pł, s. 47]. German Ritz dostrzega w tym wierszu elementy swoiste dla poetyki postmodernistycznej. Zdaniem badacza „wielość punktów widzenia, zderzanie prywatnej codzienności $\mathrm{w}$ wielkim mieście $\mathrm{z}$ apokaliptyczną rzeczywistością, bardzo dokładnie przedstawioną, ale «zminiaturyzowaną» $\mathrm{W}$ postaci audycji telewizyjnej, stanowiącej przedmiot konsumpcji, tworzy z wiersza tekst postmodernistyczny" ${ }^{26}$. Z tezą Ritza nie zgadza się Jarosław Klejnocki, uważa bowiem, że Ogladając Shoah:

to wiersz o "przebudzeniu sumienia”, eksponujący dysonans psychiczny i emocjonalny, w jakim znajduje się bohater za sprawą przywołanej z nagła pamięci historycznej $\mathrm{z}$ jednej strony a mimowolnym uczestnictwem $\mathrm{w}$ bezrefleksyjnym hic et nunc (zabawa za ścianą) $\mathrm{z}$ drugiej ${ }^{27}$.

Echa tej polemiki pobrzmiewają w kolejnych szkicach krytycznych poświęconych poezji Zagajewskiego. Czabanowska-Wróbel zdystansowała się od cytowanej wyżej wymiany zdań, pisząc: „Nie podejmuję, jak Klejnocki, polemiki z tytułowym sformułowaniem szkicu Ritza, ponieważ termin «postmodernizm» ewoluuje od 1993 roku na tyle, że nie można mu przypisać roli przezwiska czy obelgi" 28 . Z kolei Ubertowska ostrożnie wyraziła swój sprzeciw wobec niektórych wniosków Ritza: „wątpliwość budzi zwłaszcza odczytanie w Oglądając Shoah manifestu estetyki wzniosłości, rozumianej jako milczenie i odmowa" 29 .

Dyskusja wokół tego utworu, jaka przetoczyła się w przeciągu kilkunastu lat (artykuł Ritza został opublikowany w 1993 roku, książka Ubertowskiej pojawiła się w 2007 roku) pokazuje, że wiersz Oglądając Shoah nie jest jednoznaczny. Jak trafnie zauważa Czabanowska-Wróbel:

Wiersz jest znamienny dla dyskursu o Holocauście z końca XX wieku. Pośrednictwo filmu nie jest przypadkowe, nie można bowiem przyjąć postawy świadka ani sędziego, nie można dotrzeć do tamtych wydarzeń bez zapośredniczenia $\mathrm{w}$ relacjach innych ${ }^{30}$.

26 G. Ritz, Postmodernizm liryczny albo co przytrafito się Adamowi Zagajewskiemu $w$ drodze do Lwowa, przeł. A. Nasiłowska, „Teksty Drugie” 1993, nr 1, s. 67.

27 J. Klejnocki, Bez utopii? Rzecz o poezji Adama Zagajewskiego, Wałbrzych 2002, s. 125.

28 A. Czabanowska-Wróbel, Poszukiwanie blasku. O poezji Adama Zagajewskiego, s. 193.

29 A. Ubertowska, Świadectwo - trauma - głos. Literackie reprezentacje Holocaustu, s. 307.

30 A. Czabanowska-Wróbel, Poszukiwanie blasku. O poezji Adama Zagajewskiego, s. 194. 
Pozornie pośrednictwo medium, jakim jest telewizja, zapewnia bohaterowi lirycznemu psychiczny i moralny komfort: „Byłem coraz bardziej senny i niewinny. / Telewizor zapewniał mnie: my obaj / jesteśmy poza wszelkim podejrzeniem" [Pł, s. 47]. Ale czy nie ma w tych wersach cienia samooskarżenia? Ironii? Jeżeli uznamy, że słowa „coraz bardziej” odnoszą się także do przymiotnika "niewinny”, wówczas okazuje się, że to zmęczenie ciała wpływa na rosnącą obojętność wobec Zagłady? Czy zatem bohater liryczny przyznaje się przed sobą samym, że jego potrzeby fizyczne oddalają go od jednej z największych zbrodni $\mathrm{w}$ dziejach ludzkości? Nie zmienia to jednak faktu, że: „Poeta mimo wszystko jest przecież po stronie doświadczonych i pokrzywdzonych. [...] lokuje się po stronie cierpienia, choć artystycznie przejawia się to «łagodnie» - tonem elegijnym" ${ }^{31}$. Dystans, jaki zachowuje bohater liryczny, odgrywa ogromną rolę w konstruowaniu tożsamości, na co zwraca uwagę Czabanowska-Wróbel:

Dystans jest postawą uzasadnioną etycznie i warunkiem prawdziwej empatii [...]. Interpretowana przez Levinasa postawa - ,jestem odpowiedzialny" - oznacza tu paradoksalnie: nie wolno mi utożsamiać się z tym, co nie było moim udziałem, nie wolno zawłaszczać cudzego cierpienia ${ }^{32}$.

Badaczka, podobnie jak Klejnocki, podkreśla, że empatia jest widoczną cechą bohatera lirycznego wierszy Zagajewskiego. To ona, razem z dużą dozą poczucia obcości i samotności w świecie sprzyja elegijnym tonom, które dzięki próbie zbliżenia się do cierpiącego podmiotu, ale przy zachowaniu koniecznego dystansu nie zmieniają liryki w pusty lament. W przypadku omawianego wiersza ważnym czynnikiem jest świadomość tego, że nieuprawnione byłoby myślenie o możliwości utożsamienia się z ofiarami Zagłady, której nie było się świadkiem. Jak to ujmuje Czabanowska-Wróbel: „Podmiot nie epatuje chłodem, ale wie, że nie wolno mu utożsamiać się z przeżyciami ofiar, z przeżyciami, do których nie ma bezpośredniego dostępu" ${ }^{33}$.

Z kolei zdaniem Ubertowskiej w wierszu Ogladajac Shoah są „negocjowane ważne kwestie dotyczące pozycji podmiotu wobec przeszłości; niesie ona z sobą zapowiedź przemiany, przemiany bolesnej, wywołującej opór i niechęć" 34. Bohater liryczny, który jest w ciągłej podróży (obcy kraj - USA), przebywa zarazem sam (pokój hotelowy), jak i z kimś (głosy ludzi za ścianą).

\footnotetext{
31 J. Klejnocki, Bez utopii? Rzecz o poezji Adama Zagajewskiego, s. 124-125.

32 A. Czabanowska-Wróbel, Poszukiwanie blasku. O poezji Adama Zagajewskiego, s. 193.

33 Tamże, s. 194.

34 A. Ubertowska, Świadectwo - trauma - głos. Literackie reprezentacje Holocaustu, s. 307.
} 
Badaczka zauważa, że świat przedstawiony w filmie, ukazujący przecież rodzinny kraj bohatera, także wydaje mu się obcy, co przyczynia się do poczucia braku przynależności. Czuje się on bezdomny, ale w nietypowy sposób „to bezdomność po katastrofie, w świecie spustoszonym moralnie, dotkniętym erozją pamięci” ${ }^{35}$. Bohater liryczny "dąży do przezwyciężenia pozycji «fałszywego świadka», który "patrzy, ale nie widzi»" ${ }^{36}$. Niewątpliwie można interpretować Oglądając Shoah jako swego rodzaju przyznanie się do własnej winy, jak to zresztą czyni Klejnocki, który stwierdza: „W pewnym sensie wiersz ten daje się odczytać jako wizualizacja wyrzutów sumienia" ${ }^{37}$. Wydaje mi się jednak, że Ubertowska nie ma do końca racji, kiedy pisze, że:

Pojawiająca się w wygłosie wiersza fraza „Śpijmy, śpijmy, nie mamy dokąd pójść" (skierowana do nas czytelników? do ludzkości?) staje się w tym kontekście zdumiewająco wieloznaczną apostrofą, w której mieści się zarówno poczucie nagłego odarcia z sielskich wspomnień i wyidealizowanego obrazu rodzinnego kraju, pragnienie zmazania winy, jak i gorzka świadomość, że tylko sen stwarza możliwość ucieczki przed nieczułością świata ${ }^{38}$.

Rzeczywiście, jest to wieloznaczna apostrofa. Ubertowska jednak, zadając pytanie, do kogo skierowany jest ostatni wers, bierze pod uwagę dwie możliwości - odbiorcami jesteśmy my czytelnicy, a może ludzkość. Warto przypomnieć sytuację liryczną tego wiersza: za ścianą pokoju hotelowego trwają urodziny nieznajomego człowieka, bohater słyszy to, oglądając Shoah Lanzmanna i zarazem pragnąc snu. Co myśli o świętowaniu w zestawieniu z Zagładą? W jednym wersie można przeczytać, że „urodziny stawały się coraz bardziej huczne”, a po chwili, że „buty Oświęcimia skarżyły się cicho: / niestety przeżyłyśmy ludzkość", co sygnalizuje, że bohater odczuwa niekompatybilność tych dwóch obrazów świata. Powołując się na Philippe'a Lacoue-Labarthe'a, którego zdaniem „ironia jest figurą rozpaczy” ${ }^{39}$, Ubertowska dostrzega tu gorzką ironię świadczącą o bezradności bohatera ${ }^{40}$.

Istnieje trzecia możliwość rozumienia frazy „Śpijmy, śpijmy, nie mamy dokąd pójść", przy założeniu, że zostaje ona wypowiedziana przez buty ofiar Zagłady. Nie mają dokąd pójść, gdyż nie ma kto ich nosić. Skoro buty przeżyły "ludzkość", to pojawia się pytanie, czyje urodziny odbywają się

\footnotetext{
35 Tamże, s. 309.

36 Tamże, s. 310.

37 J. Klejnocki, Bez utopii? Rzecz o poezji Adama Zagajewskiego, s. 126.

38 A. Ubertowska, Świadectwo - trauma - głos. Literackie reprezentacje Holocaustu, s. 310.

39 P. Lacoue-Labarthe, Poezja jako doświadczenie, przeł. J. Margański, Gdańsk 2004, s. 89.

40 A. Ubertowska, Świadectwo - trauma - głos. Literackie reprezentacje Holocaustu, s. 309.
} 
za ścianą. Czy stwierdzenie to oznacza, że bezpowrotnie zatraciliśmy swoje człowieczeństwo? Taka konstatacja jest nie tyle ogłoszeniem nowej epoki, ile wyrazem rozpaczy przygaszonej snem, zimnej, nieczułej, właściwie nieempatycznej. Rozpaczy wynikającej z bezsilności, bezradności wobec tych, którzy zostali, wobec samego siebie. W tle wydaje się pobrzmiewać pytanie: kim jestem, jeżeli wszystkie wartości składające się na "człowieczeństwo" nie charakteryzują człowieka w czasach po Zagładzie? Taka postawa, krytyczna wobec współczesnego świata, nie jest jednostkowym przypadkiem w twórczości Zagajewskiego. Utwór Niedziela z tomu Prawdziwe życie zaczyna się tak: „Proszę bardzo, idźcie do kościoła”, a kończy strofą: „Bóg jest gdzie indziej, gdzie indziej. / My nic nie wiemy. Żyjemy w ciemności. / Bóg jest gdzie indziej, gdzie indziej" [PŻ 56]. Krytyka społeczeństwa jest w tym utworze jednoznaczna. Zakończenie Niedzieli przypomina budową omawiany utwór o Zagładzie, występują w nim bowiem powtórzenia wskazujące na bezradność podmiotu mówiącego. Bohater liryczny nie jest nawet złym prorokiem, lecz żyje w czasie, który postrzega jako apokaliptyczny. Towarzyszy mu poczucie obcości w świecie, które potrafi uciszyć za pomocą empatii. Okazuje się jednak, że empatia nie wystarcza, aby pozbyć się pewnego rodzaju obcości - obcości nie wobec ludzi, a wobec świata w ogóle. Znaczące jest motto, które towarzyszy tomikowi Prawdziwe życie, zaczerpnięte od Emmanuela Levinasa: „Prawdziwe życie jest gdzie indziej, ale my jesteśmy tutaj” [PŻ, s. 7]. $\mathrm{W}$ zdaniu Levinasa ujawnia się wiara w jakiś inny świat, $\mathrm{w}$ „prawdziwe życie", które toczy się gdzieś indziej, chociaż nie wiadomo dokładnie gdzie? Zagajewski raczej nie znalazł odpowiedzi na to pytanie, tak samo jak nie odpowiedział, jak zmieniło się znaczenia słowa „ludzkość” po Zagładzie. O tym, że taka zmiana nastąpiła, zdają się świadczyć wersy wiersza Jaskółki Oświęcimia: „W ciszy baraków / [...] / przeszywający gwizd jaskółek. // Czyżby tylko tyle zostało / z ludzkiej mowy?" [Po, s. 24]. Można zadać pytanie, ile w wyrażonej przez poetę postawie jest krytyki, o jakiej pisze Piotr Ibrahim Kalwas, formułując postulat: „Krytykuj z miłości” ${ }^{41}$, a ile krytyki wynikającej z wściekłej bezradności, z braku wiary w poprawę sytuacji.

Kolejnym utworem, który tematyzuje Holocaust, jest Jedwabne $\mathrm{z}$ tomu Anteny. Ubertowska zauważa w tym wierszu „podobny rodzaj doświadczenia - powrót wypartej pamięci o bolesnych wydarzeniach, który zmusza do ponownego przemyślenia kwestii tożsamości" ${ }^{42}$. Bohater liryczny zastanawia się nad przesunięciem znaczenia słowa ",jedwabne”, które dotychczas funkcjonowało jako przymiotnik: "Jedwabne suknie i pończochy", a obecnie

41 P.I. Kalwas, Egipt: haram halal, Warszawa 2015, s. 218.

42 A. Ubertowska, Świadectwo - trauma - głos. Literackie reprezentacje Holocaustu, s. 311. 
uzyskało nowe znaczenie: „ale to słowo będzie już teraz / brzmiało inaczej, / [...] / to słowo będzie / nas zatrzymywało" [An, s. 30]. Bohater liryczny nie musi używać nazwy Zagłada, wie bowiem doskonale, że w kręgu kulturowym jego odbiorców wyraz ,jedwabne" powszechnie kojarzy się z miejscowością o takiej nazwie, w której doszło do pogromu ludności żydowskiej, dokonanego przez ich sąsiadów - Polaków. Opowiadająca o tych wydarzeniach książka Sąsiedzi Jana Tomasza Grossa z 2000 roku odbiła się w Polsce szerokim echem, a dyskusje nad nią trwają do dzisiaj. Ubertowska, analizując wiersz Jedwabne, dochodzi do kilku ciekawych wniosków dotyczących postawy bohatera lirycznego. Użycie zwrotu "to słowo" w trzecim i przedostatnim wersie jest chwytem poetyckim, który „zaznacza «niewysławialne», sferę społecznego «tabu», w której czytelnik rozpoznaje nieznane, straszne oblicze społeczności, z którą się utożsamia" ${ }^{43}$. Warto podkreślić, że utożsamia się $\mathrm{z}$ nią również bohater liryczny, przemawiając $\mathrm{w}$ imieniu zbiorowości, na co wskazuje liczba mnoga użytych czasowników, np. „będziemy się zatrzymywali". Ubertowska trafnie zauważa, że:

Obranie tej formy podmiotowej jest wyrazistą deklaracją zapowiadającą po-
szukiwanie w języku obszarów, o które zaczepia się społeczna (historyczna)
świadomość. [...] W ujęciu Zagajewskiego bowiem wspólnotowy wymiar języka
tworzą słowa-urazy, [...], albo też, przeciwnie, gesty zaprzeczenia, mechanizmy
obronne. Słowa te mają moc łączenia wszystkich przedstawicieli wspólnoty bez
względu na status społeczny, wykształcenie, miejsce zamieszkania, uświada-
miając w sposób dobitny, że spokrewnia ich szczególny rodzaj doświadczenia,
jakim jest zadomowienie, „zanurzenie” w języku rodzimym ${ }^{44}$.

Bohater liryczny wypowiada się w imieniu wspólnoty, a utożsamiając się $\mathrm{z}$ narodem, utożsamia się z jego historią, także tą niechlubną. Wypowiadanie się $\mathrm{w}$ imieniu całej zbiorowości ma również wymiar etyczny - bohater nie tyle może chce przepracować traumę (czy jest to możliwe?), ile nie zamierza tej części historii ukrywać. Przy tym słowie "będziemy się zatrzymywali", ale i ono "będzie nas zatrzymywało". Pierwszy zwrot można rozumieć jako apel o pamięć, o dyskusję nad tym wydarzeniem, o niezgodę na pomijanie go w historii. Drugi jest stwierdzeniem o wymiarze etycznym: „przecież inaczej nie można". Zdaniem Ubertowskiej bohater wiersza realizuje postawę etyczną, scharakteryzowaną przez Levinasa, a zakładającą "nieustanne weryfikowanie podstaw, na jakich ufundowana została tożsamość grupy, wspólnoty etnicznej poprzez samoograniczenie, krytyczną refleksję nad sobą i ję-

43 Tamże, s. 317.

44 Tamże, s. 318. 
zykiem, za pomocą którego artykułowany jest obraz świata i międzyludzkich relacji" ${ }^{45}$. Nieco wcześniej badaczka słusznie zauważa, że:

Wraz z ukonstytuowaniem się "my" inkluzywnego zostaje przekroczony ego-iczny wymiar poezji, poszerza się perspektywa doświadczania świata. Nadal jednak wypowiedź poetycka zachowuje znamiona lirycznego wyznania, dominuje w niej ton intymny, osobisty. Powstaje wrażenie, że ta osobowa sygnatura jest czymś niezmiernie istotnym, wartością dostarczającą utworowi Zagajewskiego szczególnej legitymizacji ${ }^{46}$.

Biorąc odpowiedzialność za historię narodu oraz przyjmując rolę strażnika pamięci - bo przecież Jedwabne jest wierszem upominającym się o pamięć o zamordowanych sąsiadach-Żydach - bohater Zagajewskiego staje się elegistą.

\section{Czas podsumowań}

Interesującym przykładem realizacji formy elegijnej jest wiersz Skończyła się rewolucja [NR]. Zagajewski powraca w nim do czasów swojej młodości, gdy jego poezję utożsamiano $\mathrm{z}$ postulatami Nowej Fali. Konfrontuje czas teraźniejszy z czasem przeszłym, siebie zbuntowanego z sobą oddalającym się coraz bardziej od zaangażowania w życie polityczne kraju. Dopisek pod wierszem: "[Pamiętajac o smutnych rewolucjonistach Juliana Kornhausera]" jednoznacznie wskazuje na okres komunizmu, w którym poeta podjął nie tylko walkę polityczną, ale także walkę o kształt literatury. Pokolenie Zagajewskiego na dobre zagościło na polskiej scenie literackiej w latach 70., kiedy to, jak pisze Stanisław Burkot, „do literatury wkracza generacja urodzonych po wojnie, której świadomość kształtowały już inne okoliczności życia społecznego. Hasłem wywoławczym, jednoczącym młodych - od Lipskiej do Kornhausera - są słowa «bunt» i «teraźniejszość»" ${ }^{47}$. Dopisek w wierszu Zagajewskiego odsyła do tomiku Kornhausera z 1973 roku W fabrykach udajemy smutnych rewolucjonistów. Jak wyjaśnia Burkot: „Ironiczny tytuł całego tomiku, a także tytuły poszczególnych utworów [...] odczytywać należy jako próbę realizacji zasady podstawowej - jedności słów i czynów, haseł i dokonań, poezji i życia" 48 . Z kolei zdaniem Adriana Glenia:

\footnotetext{
45 Tamże, s. 319.

46 Tamże, s. 318.

47 S. Burkot, Spotkania z poezja wspótczesna, Warszawa 1977, s. 309.

48 Tamże, s. 319.
} 
Postulat zaangażowania w literaturze oznaczał dla Juliana Kornhausera konieczność przede wszystkim bycia nieufnym zarówno wobec kłamstwa obecnego w przestrzeni publicznej, jak i samej „literackości” (estetycznego, pięknego układania słów), stanowiących zagrożenie dla naczelnej zasady życia i pisania - prawdy $^{49}$.

Zagajewski mierzy się w swoim wierszu z rzeczywistością, która nastała po rewolucji zarówno politycznej, jak i poetyckiej. Czas podsumowania przychodzi dosyć późno, gdyż utwór znalazł się w tomie z 2009 roku, a więc dwadzieścia lat po upadku komunizmu w Polsce. Postulaty Nowej Fali Zagajewski formułował jeszcze wcześniej. Przemyślenia bohatera wiersza przesycone są goryczą. Co prawda wers „życie wskazywało tendencję zwyżkową" [NR, s. 33] sugeruje, że po skończeniu rewolucji nastał lepszy czas, ale bohater liryczny nie potrafi określić, kto jest zwycięzcą, a kto przegranym: „i nie zranić ani pokonanych, ani zwycięzców, / ani tych, co jeszcze nie wiedzieli, / po której stronie się znaleźli, / czyli praktycznie nas wszystkich / piszących i czytających te słowa" [NR, s. 33]. Wiersz ten można uznać za interpretację ówczesnej polityki, gdyż okres po 1989 roku nie przez wszystkich Polaków wspominany jest dobrze. Nie wszyscy odnaleźli się w nowej rzeczywistości, a opozycja antykomunistyczna rozdrobniła się na wiele skonfliktowanych obozów. Dawni sojusznicy stawali się przeciwnikami. Utwór ten niesie znane przesłanie, że rewolucja pożera własne dzieci. Odwołując się do tomiku Juliana Kornhausera, Zagajewski niejako konfrontuje postulaty dotyczące literatury z rzeczywistością i pyta, czy udało się osiągnąć to, o co walczyli Nowofalowcy, a mianowicie jedność słów i czynów, haseł i dokonań, poezji i życia.

Odchodząc od nowofalowego myślenia, Zagajewski oddalił się również od życia politycznego, co skutkowało, jak można wnosić z wiersza Żal po utracie przyjaciela [As], konfliktami z dawnymi przyjaciółmi. Utwór ten, będący elegię nietypową, ponieważ dotyczącą osoby żywej, traktuje o kimś, kto mocno zaangażował się politycznie: „Mój przyjaciel ukrywa się przede mną / Pochwycił go głęboki prąd polityczny" [As, s. 57]. Bohater liryczny negatywnie ocenia nadmierne zaangażowanie się w świat polityki, uważa bowiem, że przysłania ona inne, równie ważne aspekty rzeczywistości: „Mój przyjaciel wieczorem nie wychodzi / z domu nawet w maju gdy wszystkie / domy śpiewają a jaskółki znikają w niebie / na długo i wracają stamtąd wesołe / pozbawione trosk, odnowione" [As, s. 58]. Różnica poglądów tak wpłynęła na relacje bohatera lirycznego z "przyjacielem”, że pisze pełną gorzkich słów i żalu elegię o żyjącym człowieku.

49 A. Gleń, Języki rzeczywistości. O twórczości Juliana Kornhausera, Kraków 2018, s. 43. 
Zestawiając ze sobą wiersze Skończyła się rewolucja oraz Żal po utracie przyjaciela, powstałe w stosunkowo niewielkim odstępie czasu, można wnioskować o rozczarowaniu rzeczywistością, którą czas nieubłaganie weryfikuje. Wprawdzie rewolucja się skończyła, jednak nie wiadomo, kto jest zwycięzcą. Zmiana myślenia, zmiana priorytetów przyczyniła się do zerwania przyjaźni. Bohater liryczny nie może się z tym faktem pogodzić, ale z gorzką ironią przyjmuje go do wiadomości. Nie zgadza się, gdyż wciąż używa słowa „przyjaciel”, zgadza się, gdyż pisze o nim elegię. Pamiętając o „smutnych rewolucjonistach" Juliana Kornhausera, o postulatach poetów Nowej Fali o jedności poezji i życia, jako ironiczne trzeba odczytywać wersy „Mój przyjaciel uważa, że jestem / [...] / beznadziejnie zagubiony w nurtach / nieodpowiedzialnych epitetów / w groźnym gąszczu niedopowiedzeń / Mój przyjaciel wie co jest kotwicą naszego życia / co jest niezbędną hiperbolą a co tylko litotą" [As, s. 57-58]. W tym fragmencie poezja miesza się z życiem, a figury poetyckie służą nazwaniu tego, co bohatera lirycznego rozdzieliło z przyjacielem. Ale na tym nie koniec - $w$ utworze jest jeszcze jeden ważny wers: „mój przyjaciel / nie ma czasu na metaforę ani na pars pro toto". Przyjaciel, który całkowicie zaangażował się w politykę, w sprawy narodu, nie ma czasu na takie życie, które jest istotne dla ceniącego sobie indywidualność bohatera Zagajewskiego. Co prawda często poszukuje on wspólnoty, ale nie zamierza się $\mathrm{w}$ niej zatracić, utożsamić się z nią w sposób całkowity.

W poezji Zagajewskiego częste powroty do przeszłości - w jej wymiarze indywidualnym i zbiorowym - nie są wyłącznie nostalgicznymi wtrąceniami. Jak zauważa Czabanowska-Wróbel:

Zagajewski zdaje się mówić, że duchowa restytucja jest możliwa jedynie pod warunkiem pracy pamięci, stałego zbierania głosów i śladów. Tylko tak może nastąpić odbudowa tożsamości. [...] Elegia powraca do przeszłości, także po to, by ją uzdrowić - dla przyszłości ${ }^{50}$.

Możliwe, że właśnie z chęci „uzdrowienia przyszłości” wynika krytyka otaczającego świata, niekiedy przybierająca ton rezygnacji, niewiary, rozpaczy. Jednak bohater liryczny nie porzuca swojej wędrówki, wciąż „kocha światło" i szuka go w świecie, którego niezaprzeczalne wady dostrzega. Zdaniem Walcotta Zagajewski jasno określił, do czego dąży: „Tym celem, jak sam autor pisze, jest «próbować opiewać okaleczony świat». Wystarczy otworzyć tom jego poezji w dowolnym miejscu, i natychmiast się to ujawnia" ${ }^{51}$. Być może jest $\mathrm{w}$ tym stwierdzeniu pewna przesada, chociaż rzeczywiście zachwyt nad

\footnotetext{
50 A. Czabanowska-Wróbel, Poszukiwanie blasku. O poezji Adama Zagajewskiego, s. 165.

51 D. Walcott, Elegista, s. 27.
} 
światem, pozwalający mimo wszystko dostrzec jego „okaleczenie”, jest wyraźny w poezji Zagajewskiego. Trzeba się zgodzić, że ,jego ściszony głos dobiega spoza katastrofalnych zniszczeń tego obscenicznego wieku" ${ }^{\prime 52}$. Jest to głos nie tylko opiewający "tu i teraz", ale także głos strażnika pamięci, który przechowuje pamięć o przeszłości, a jednocześnie pozwala jej oddziaływać na przyszłość. Czyni tak, ponieważ - jak deklaruje w wierszu Jesteście moim milczacym rodzeństwem - ci, którzy odeszli, są mu wciąż bliscy: "Jesteście moimi mistrzami, / umarli. / Nie zapomnijcie o mnie" [ZO, s. 28]. Czyż nie płynie z tych słów przesłanie, że zapominając o przeszłości, sami skazujemy się na zapomnienie?

\section{Bibliografia}

Biedrzycki Krzysztof (2008), Poezja i pamieć. O trzech poematach Czesława Miłosza, Zbigniewa Herberta i Adama Zagajewskiego, Kraków: Wydawnictwo Uniwersytetu Jagiellońskiego.

Burkot Stanisław (1977), Spotkania z poezja wspótczesna, Warszawa: Wydawnictwo Szkolne i Pedagogiczne.

Czabanowska-Wróbel Anna (2005), Poszukiwanie blasku. O poezji Adama Zagajewskiego, Kraków: Universitas.

Doktór Roman (1999), Polska elegia oświeceniowa, Lublin: Katolicki Uniwersytet Lubelski.

Gleń Adrian (2018), Języki rzeczywistości. O twórczości Juliana Kornhausera, Kraków: Polskie Wydawnictwo Muzyczne.

Kalwas Piotr Ibrahim (2015), Egipt: haram halal, Warszawa: Wydawnictwo Dowody na Istnienie.

Klejnocki Jarosław (2002), Bez utopii? Rzecz o poezji Adama Zagajewskiego, Wałbrzych: Ruta.

Kuczera-Chachulska Bernadetta (2002), Przemiany form i postaw elegijnych w liryce polskiej XIX wieku, Warszawa: Wydawnictwo Uniwersytetu Kardynała Stefana Wyszyńskiego.

Lacoue-Labarthe Phillippe (2004), Poezja jako doświadczenie, przeł. J. Margański, Gdańsk: Słowo/Obraz Terytoria.

Legeżyńska Anna (1999), Gest pożegnania. Szkice o poetyckiej świadomości elegijno-ironicznej, Poznań: Poznańskie Studia Polonistyczne.

Piotrowska Henryka (1977), Elegia, w: Słownik literatury polskiego Oświecenia, red. T. Kostkiewiczowa, Wrocław: Ossolineum, s. 93-99.

Ritz German (1993), Postmodernizm liryczny albo co przytrafito się Adamowi Zagajewskiemu w drodze do Lwowa, przeł. A. Nasiłowska, „Teksty Drugie”, nr 1, s. 55-73.

52 Tamże, s. 27-28. 
Ubertowska Aleksandra (2007), Świadectwo - trauma - głos. Literackie reprezentacje Holocaustu, Kraków: Universitas.

Walcott Derek (2015), Elegista, przeł. R. Gorczyńka, w: I cień i światło... O twórczości Adama Zagajewskiego, red. A. Czabanowska-Wróbel, Kraków: Wydawnictwo a5, s. 9-28.

Zagajewski Adam (1990), Płótno, Paryż: Zeszyty Literackie.

Zagajewski Adam (1991), Dwa miasta, Paryż: Biblioteka Zeszytów Literackich, Kraków: Oficyna Literacka.

Zagajewski Adam (1994), Ziemia ognista, Poznań: Wydawnictwo a5.

Zagajewski Adam (2003), Powrót, Kraków: Wydawnictwo Znak.

Zagajewski Adam (2005), Anteny, Kraków: Wydawnictwo a5.

Zagajewski Adam (2009), Niewidzialna ręka, Kraków: Wydawnictwo Znak.

Zagajewski Adam (2014), Asymetria, Kraków: Wydawnictwo a5.

Zagajewski Adam (2019), Prawdziwe życie, Kraków: Wydawnictwo a5.

\title{
Different Faces of Elegy in the Poetry of Adam Zagajewski
}

\begin{abstract}
The article analyses Adam Zagajewski's poems that observe the elegiac convention. While summarizing the existing critical thought on the function of elegia in Zagajewski's poetry, the author presents his own interpretations of selected works. He proves that the elegiac form, realised in Zagajewski's work in many different ways, is not just an expression of the poet's nostalgia for the past. By recalling past events, by remembering his deceased friends, and by maintaining the memory of the victims of the Holocaust, Zagajewski makes the lyrical hero of his poems the guardian of the past. This remembrance must be allowed to influence the future.
\end{abstract}

Keywords: elegy, contemporary Polish poetry, memory, past, Adam Zagajewski 